Handayani, J. S., Lestari, P. D. and Agave, A. (2020), "Implementation of Kanagoods marketing public relations program in creation of brand image of Batik Indigo Company", Management and entrepreneurship: trends of development, Volume 3, Issue 13, pp. 87-96, available at: https://doi.org/10.26661/2522-1566/2020-3/13-07

MARKETING

\section{RECEIVED:}

11 September 2020

ACCEPTED:

11 October 2020

RELEASED:

20 October 2020
UDC 339.138

DOI 10.26661/2522-1566/2020-3/13-07

\title{
IMPLEMENTATION OF KANAGOODS MARKETING PUBLIC RELATIONS PROGRAM IN CREATION OF BRAND IMAGE OF BATIK INDIGO COMPANY
}

\author{
Jihan Syavira Handayani \\ London School of Public Relations \\ Jakarta, Indonesia \\ ORCID: 0000-0003-0668-8101
}

\author{
Permata Dwi Lestari \\ London School of Public Relations \\ Jakarta, Indonesia \\ ORCID: 0000-0003-0682-5647
}

\author{
Angela Agave \\ London School of Public Relations \\ Jakarta, Indonesia \\ ORCID: 0000-0001-8560-891X
}

*Corresponding author email: permatadwilestarii97@gmail.com

\begin{abstract}
Kanagoods is the first mover for batik producer with coloring technique by using indigo as the main natural ingredient. The company was built in 2012 and is running the program through the Implementation of Marketing Public Relation to build the brand image as batik producer and to find any obstacles as well as Kanagoods efforts in solving the obstacles. The purpose of the article is to increase the efficiency of marketing activities of Kanagoods by improving the marketing program for public relations through creating a brand image of Batik Indigo. This research focuses on 7 main activities of Public Relations Marketing, consisting of Publications, Events, News, Community Involvement, Information or images, Lobbying and negotiations, and Social responsibility. The theory used in the result of this study indicated that Kanagoods uses the concept of Marketing Public Relations from Thomas L. Harris namely PENCILS that explained why Kanagoods used the 7 tools to improve the image. Based on the result, it can be concluded that the most suitable activity to use was Events. However, the overall conclusion is that every strategy used by Kanagoods to build their brand image consider as quite effective, related to the public target, and obtain the expected result.
\end{abstract}

Keywords: Kanagoods, marketing public relations, brand image.

JEL Classification: D29, M31, L 67.

\section{INTRODUCTION}

Etymologically, Batik comes from the javanese language "amba" which means wide and large fabric. And "titik" that means doing works by making dots pattern developed into the new term of batik, which means "connecting dots"and becomes a certain pattern in wide and large fabric (Wulandari, 2011). Based on the definition from The Minister of Manpower through the standard of National work competence number 314/2013 who explained that batik is a dyeing technique art of textile which in the process of making uses wax as a resistor and use canting or stamp to stick the color (Mulyanto, 2016).

Nowadays, batik has been transformed as home decoration and fashion trend, a handcraft that is able to touch various levels of society, every ages and livelihoods of both domestic or foreign 
people. In October 2017 the export value of batik and various batik products continued to increase and reach US \$ 51.15 million, which originally US \$ 39.4 million in January 2017. With the main marketing targets Japan, US and Europe. (Kementerian Perindustrian Republik Indonesia, 2018)

Currently the creative industry in Indonesia is growing rapidly, from culinary, IT, art and fashion. In this modern era, fashion is one of the biggest contributors to the country's exchange rates. Since 2012-2017, the industrial minister has facilitated 462 exhibition stands for the national fashion industry to promote their superior products. (Kementerian Perindustrian Republik Indonesia, 2018).

Batik as original cultural heritage of Indonesia is often considered as an old trend and does not reflect the contemporary development. This makes batik less attractive to young people or millennials. Therefore, currently various local Indonesian products are trying to make changes of Batik market targets.

Kanagoods is an original Indonesian brand that carries the concept of natural materials with indigo plants as natural colour. By using indigo leaves and contemporary batik crafts for men and women that are suitable for all generations, the founder established Kanagoods Company.

\section{LITERATURE REVIEW}

Batik making by natural coloring technique can be used indigo leaves (Indigofera tinctoria), indigo color or tarum. Indigofera tinctoria is a plant that produces natural blue color. The use of clothing dyes mainly carried out in the manufacture of batik or traditional tied weaving technique from archipelago (Muzzazinah, Chikmawati, Rifai and Ariyanti, 2014)

The product quality consider as premium for its target market where this brand does not have any offline store and only relies on Marketing public relations as a media for conveying the message of this product. Examples of Marketing Public Relations that currently used are participating in local Indonesian brand exhibitions, conducting collaboration with digital marketing, and doing sponsorship to introduce their products. Kanagoods Batik includes 5 Sustainable Indonesian Fashion Brands That You Can Wear and Save the Earth with as one of brand slowfashion with environment friendly (Levina, 2016).

The concept of MPR (Marketing Public Relations) comes from Kotler who set the concept of Mega Marketing as the collaboration of Public Relation strength and Marketing, after that there is a new term called Marketing Public Relations which was introduced by Thomas L. Harris. In his book The Markerter's Guide to Public Relations he stated that MPR is the planning process and program evaluation that stimulates the outcomes of sales and customers. This was done through the communication of credible information and impressions that can connect the company, its products with customers' need and concern. (Ruslan, Rosady, SH, 2014).

According to Harris the main reason of MPR aims to increase awareness, stimulate sales, and facilitate communication to build relation among customers, companies and brands. This research limits MPR analysis of Kanagoods only on the efforts to stimulate and facilitate communication and build its image as batik indigo producer (Harris, 2006).

Based on the definition above, MPR have an important role in building the brand image. This research tried to examine the role of MPR in building the brand image of Kanagoods batik indigo, which creates a positive image of customer. Therefore, the customer can be a loyal customer of the product. This research tried to find out the implementation of MPR of Kanagoods program to build the brand image as a slow-fashion batik indigo producer in 2018. Thus, the purpose of this study was to determine and analyse the implementation of MPR in building brand image as 2018 slowfashion indigo batik producer. 
Handayani, J. S., Lestari, P. D. and Agave, A. (2020), "Implementation of Kanagoods marketing public relations program in creation of brand image of Batik Indigo Company", Management and entrepreneurship: trends of development, Volume 3, Issue 13, pp. 87-96, available at: https://doi.org/10.26661/2522-1566/2020-3/13-07

\section{PAPER OBJECTIVE}

The purpose of the article is to increase the efficiency of marketing activities of Kanagoods by improving the marketing program for public relations through creating a brand image of Batik Indigo.

\section{METHODOLOGY}

This research used qualitative research method. Qualitative data analysis is inductive, which means an analysis based on the obtained data, then developed into a hypothesis. This research was done by organizing data, arranging them into patterns and choosing which ones are important to learn (Sugiyono, 2016). As what was stated by Ardianto (2009) Communication in positivism paradigm is a linear process or causal process that can reflect the sender's efforts to change the knowledge of recipient's message. The informant chosen to provide information consists of four people, which includes two people from internal part, and the other two from external parties as consumers of Kanagoods.

In this research, Data collection was done by two steps: the secondary data and the primary data. The secondary data was taken from internet and other secondary media. And the primary data was taken from information collection such as participation in regulations, direct observation, indepth interviews and documentation review.

This Research was done during September 2018 to January 2019, the exact time to collect the complete and accurate data. This research was conducted at the Kanagoods workshop in Pamulang, South Tangerang.

The Analysis of the Kanagoods Marketing Public Relations

In order to achieve the objectives of the company, there are seven main activities for MPR's publication activities (Harris, 2006). The activities consist as Event organizing, News, Community Involvement, Inform on Image, Lobbying and Negotiation, Social Responsibility.

The Following results of the research will be described one by one according to the information provided by Kanagoods, related to MPR activities. This analysis begins with the profile of interviewees, and then an analysis of each element can be seen as follows.

\section{Publicity}

According to Harris (inside Ardianto, 2009) Publication means to organize publications and disseminate information through the media regarding various activities of the company that should be known by public. Therefore, publicity can get a broad positive response from society.

From the very beginning of the Kanagoods establishment, this company used more social media during publicity activities and also public communication; they tend to use social media such as Instagram, Facebook or by online website. Magazine, television and workshop as media approach to introduce the brand image.

This was confirmed by the opinion of Sancaya Rini, who said that the influence of social media depends on the public reaction. It is important to manage and update the content of social media. Apart from getting publicity it is also necessary to obtain positive feedback from society. As the owner, Sancaya Rini communicates with public and makes changes in goals to be achieved, which involve Kanagoods to be well known.

The effective of social media promotion can be proven by the increasing number of followers on Kanagoods social media. This number also increases whenever Kanagoods uploads new photos or videos on Instagram. As Kanagoods attend an event, the number of followers will increase as well. 
The production activities of Kanagoods are based on the publicity and attract the consumers' interest displayed in Kanagoods social media. Media concept is a tool and facility of communicators to convey their messages to public (Cangara, 2002).

From the explanation above, researcher make the temporary conclusions regarding by the implementation of Kanagoods MPR, Kanagoods only active doing publicity by social media, because it is related with its target public media. Based on the informed content of publicity activities by Kanagoods, the brand can be easily accepted by consumers, and the frequency of 2018 Kanagoods Publicity is not as massive as the previous years.

According to the analyzed publicities, social media should frequently update Kanagoods activities. In the opinion of Matt Smith, the owner of Lattergamme, the accurate time to update their activities was 2AM to 5PM, because this range hour is the best time to post Instagram and many public targets are active at this period, therefore it will be better if the owner regularly uploads new content during the determined hour.

As a result consumers who become informant are attracted by the activities of publicity. However, according to interviews, for several reasons, there are consumers who are less aware regarding the publicity activities because of inappropriate media use.

\section{Event}

For event promotion, Kanagoods often participates in local brand events organized by wellknown Indonesian brands such as Bekraf, Inacraft, Popup, Brightspot, etc. As it is explained by Cangara (2009) in his book, Media is a tool or facility used to convey messages from communicators to public, and the type of media used is public media because it is intended for public around the city which organizes an event.

Kanagoods uses event to implement Marketing Public Relation activities, in this case the types of events used are exhibitions, workshops, and talk shows. Besides sharing the knowledge, this kind of event is also used to introduce the brand to public.

According to Ms. Sancaya Rini, the exhibition is one of the events to promote the products, and she stated that: "Exhibition, is one of promotional activities, such as Bright spot, Pop up market, Ina craft, local market" (S.Rini, private communication, April 02 2019)

Alonside with exhibition the MPR activities used by Kanagoods also include workshops and collaboration with marketplace industry. The purposes of Kanagoods' attending an event and exhibition is to introduce the product in wider area to be more well-known. According to the opinion of the owner this will affect the brand image.

Participating in various exhibition events has yielded many results including getting Kanagoods more familiar within the target public. It also achieves other purposes, such as maintaining good relations between Kanagoods' owners and staff on the one hand and public on the other. It also becomes an educational program to other small related industries.

The explanation above indicates that the implementation of MPR Kanagoods' event is effective to promote it with the correct public target and marketing target. Kanagoods only participates in an event, the segmentation of which is appropriate to their public target. It can be proven that MPR event activities can achieve the expected sales target by the company.

\section{News}

As Kanagoods often attends the exhibition, media become interested in covering Kanagoods in their workshops to discuss more about batik indigo, how to make it, as well as advantages and disadvantages of its products. 
Handayani, J. S., Lestari, P. D. and Agave, A. (2020), "Implementation of Kanagoods marketing public relations program in creation of brand image of Batik Indigo Company", Management and entrepreneurship: trends of development, Volume 3, Issue 13, pp. 87-96, available at: https://doi.org/10.26661/2522-1566/2020-3/13-07

That is also a positive point for public promotion of the Kanagoods' image as a batik indigo producer because they can see the product-making process through media coverage and recognize the brand regarding Kanagoods' environmental friendly products.

Keller stated that a brand has to own a unique and good image to consumer. Based on the opinion of Kanagoods, the news approach was not as big as in previous years. In her statement, Sancaya Rini added that any news regarding Kanagoods was not followed up (Kotler and Keller, 2012).

Based on the explanation above, News as the implementation of Kanagoods Marketing Public Relation includes an accurate promotion method because the message can be conveyed properly through media with the expected result of Kanagoods. However, the media chosen by Kanagoods is large mainstream media, mainly social media. Thus Kanagoods does not follow up on news about the company and there is no percentage of media cover on Kanagoods.

\section{Community Involvement}

To maintain good relations with stakeholders, Kanagoods is divided into two parts - external and internal. The first part is external, for the sake of business continuity it is better to establish relationships with stakeholders, the strength of brand associations provides information and establishes relationships that can be remembered by consumers or stakeholders. Thus, it can be a factor in building a brand image (Eka Saputri and Ratna Pranata, 2014).

In this case Kanagoods maintains its good relationship not only for consumer side but also for the entire aspects or supported parties, including maintaining the communication with the employees because they hold the prosperity of the company. Thus, the response and communication from stakeholders, both internal and external remains good.

Kanagoods involves internal and external stakeholders through social media of the MPR activities. However Kanagoods did not make continuous progress with their consumers about the products by introducing the batik indigo community, therefore it will help to build good relationship.

\section{Inform or Image}

Coloring fabrics by natural materials such as indigo leaves and other plants are materials that are not commonly used in fashion industry. By the strength of brand association, the input information on consumers' memory can be done and becomes a brand image which can create strong association of consumers (Eka Saputri and Ratna Pranata, 2014)

To spread the information about Kanagoods' products, there are activities carried out by the company in order to convey information to the public. In public relations activities it must have benefits on conveying information. Kanagoods has certain indicators to measure the success of public relations activities. In carrying out MPR activities, Kanagoods carries out certain strategies, these strategies can be different themes for each season of the products they have, and therefore, the consumer or their target is aware whenever they launch a new product.

In MPR's activities carried out by Kanagoods, it has the goal to achieve an expected plan of the company. As Sancaya Rini stated the success indicator of MPR's activities is not only in form of the number of followers but also how consumers appreciate the concept of products. And that is an important point of MPR (Marketing Public Relations) to strengthen the point of marketing itself, and not to sideline MPR (Gani and Amalia, 2014).

Based on the explanation above, it can be concluded that image as the implementation of MPR was implemented effectively, because the information is well-conveyed and brand image can be well known to public. It really influences Public Relation activities carried out by Kanagoods as 
far as brand awareness is concerned. However, the obstacle due to the lack of human resources in the field of Public Relations causes the sales decrease in comparison with the previous ones. The public image of Kanagoods is considered as good, because the product has strong branding.

The success indicator on Kanagoods social media is measured by the increase of followers of Kanagoods social media. Another indicator is aftersales from consumers who repurchase the products of Kanagoods, and also consumers who are loyal to the Kanagoods brand. Kanagoods mostly uses events on its MPR strategy, with the aim to introduce the latest products or themes in order to make the brand known by the public.

Public Relation Kanagoods activities have obstacles, such as public targets or sales targets that are not achieved as it is expected by the plan. Kanagoods also carried out a strategy to fix the obstacles. The strategy used by Kanagoods to build the better brand image included reviewing all the strategies previously applied to improve its future strategies.

\section{Lobbying and Negotiating}

In order to maintain the company there must be many supporting factors to keep the business working. In this case there is a factor that supports the production activities of Kanagoods Company, such as institutions that influence the life of the company. Another institution that has influence on Kanagoods is Bekraf. Bekraf is a government agency and a forum for Kanagoods to introduce its products abroad and it also expands the public market.

Another point is that Kanagoods also maintains a good relationship by interacting with their consumers and more active using social media because through social media, consumers can easily update the products and their testimonials or responses to the products from comments column.

Based on the explanation above, Lobbying and Negotiation is an implementation of MPR by Kanagoods to keep good relationship with big industries which will affect the company through either production activities or event organizing to introduce the product. Kanagoods does not have a specific strategy to maintain good relations with institutions that influence the company. By inviting Kanagoods to every event held by related institutions, it can be a measure of Kanagoods success to maintain good relations.

\section{Social Responsibility}

In public relations activities, demonstrating the concern for the surrounding, Kanagoods also shows its concern by holding social activities in its production house. Furthermore, social activities are involving people both around the production house and in the rural place.

Kanagoods conducts social responsibility activities by educating public about batik indigo, they hold the workshop without any charge, reminding that Kanagoods originates from workshop within the people around. Kanagoods expected to gain empathy from people around and that proves that Kanagoods does not only think about profit but also cares for society.

On the implementation of social responsibility, Kanagoods has various public targets. The implemented activities can be workshops on dyeing batik cloth by natural materials; this activity was carried out by Sancaya Rini as the owner of Kanagoods to control rural areas such as the Toba.

Based on the explanation above, the publicity of the MPR Kanagoods' social responsibility consists in the activity of introducing indigo batik to society. The public is aware of these workshop activities and is also interested in knowing more about workshop activities, however there are also consumers who are not aware of these activities.

Workshop of social responsibility activity is mainly targeted at young people who want to learn more about indigo coloring techniques. On implementating these activities, Kanagood does not set any schedule. The concept of this activity is sharing knowledge regarding the product and the technique of indigo coloring. 
Handayani, J. S., Lestari, P. D. and Agave, A. (2020), "Implementation of Kanagoods marketing public relations program in creation of brand image of Batik Indigo Company", Management and entrepreneurship: trends of development, Volume 3, Issue 13, pp. 87-96, available at: https://doi.org/10.26661/2522-1566/2020-3/13-07

\section{RESULTS AND DISCUSSION}

\section{The Implementation of Marketing Public Relation in Kanagoods}

Publications of the Kanagood activities can be found in various media - from traditional to online. The disadvantage of using traditional media in publicity is due to its passive character, including the problem of inappropriate media use for the target public. On the other hand, the advantage of such active media user as social media is its addressing to the target public.

Kanagoods content of publicity has been accepted by consumers. It is also known that in 2018 the frequency of Kanagoods Publicity is not as massive as in the previous years. As stated by Keller, Publicity activities considered as an effective promotion because it includes necessary MPR factors. Nowadays consumer's attention and interest of advertisement is starting to be decreased, the messages in advertisements tend to be excessive and boring and difficult to gain attention from consumers (Kotler and Keller, 2012).

Event, Kanagoods is really active on conducting exhibition and workshops by collaboration with marketplace industry. The selection of events to support the Kanagoods MPR activities was chosen based on its public targets. In organizing activities of an event, the program segmentation relates to their public target. Based on the findings, it shows that MPR event activities can achieve the sales target.

During the implementation of an event, Kanagoods used media during the exhibition by updating and spreading information by social media. This activity is considered effective to increase people's awareness and the number of followers (Wahid and Rizki, 2018), where it may affect the product brand image.

News issues and values that Kanagoods wants to convey through the news and media can be well received and meet the expectations of Kanagoods. This research found out that, the selection of media used by Kanagoods was big media, mainstream media that not all of the target public used. In scope of media presentation, Kanagoods did not follow up the news regarding the company, and there is no media presentation about Kanagoods.

Kanagoods used media as their facilitators to convey the message to public with an expectation that the news spread within the wider audience. As it was implied by Cangara to promote the media for public in every location, there were used social media to convey the message from informant by such mechanical communication tools as newspaper, film, radio, and television (Cangara, 2002).

Kanagoods Community Involvement engages its internal and external stakeholders through social contacts in the MPR's activities. Kanagoods did not obtain the continuous communication with consumers to introduce Batik Indigo

Because of the fact that Kanagoods regularly conducts social contact, its relation with stakeholders is quite good. Information and Images of events are used as a tool to convey information and images about their products to consumers and this can help to do it properly.

Public Relations really influence the brand awareness of Kanagoods. This brand awareness will help to introduce the brand and product. However, due to the lack of Public Relations human resources at Kanagoods, product sales are not as high as before.

Consumers state that the image of Kanagoods is good, because they have strong branding. However, as far as aftersales are concerned Kanagoods does not involve continuous relation with their old customer.

According to Kanagoods, its success indicator in social media is measured by the increase of social media followers and other indicators are aftersales from consumers. They repurchase Kanagoods products and there are several consumers who are loyal to Kanagoods. Kanagoods tend to obtain an event as MPR's strategy, with a purpose to introduce its latest product to massive public. 
The Kanagoods Public Relation activities have an obstacle which includes the public target and planned sales target. The Strategy used by Kanagoods to establish the brand image consists in reviewing the entire strategy previously applied to improve further strategy.

This is one of the MPR roles to foster and maintain the company's images, products and services, both in terms of quantity and quality of services provided to consumers as well as to provide the clear information to public. Therefore it will inform the public regarding brand image (Ardianto, 2009)

Lobbying \& Negotiations can help Kanagoods to maintain good relations with the institutions that influence the company, due to production activities or from event organizing to introduce the brand. Kanagoods does not have specific strategy to maintain good relations with institutions that influence the company, it relies on friendly relation to maintain their good relation. By inviting Kanagoods at every event held by related institutions, it can measure the Kanagoods success level to maintain their good relations with other parties.

Kanagoods's CSR activity is aimed at introducing and educating people concerning coloring technique by natural indigo coloring tools. Due to the activities consumers are attracted to know more about CSR (workshop) events, but there are also customers who are not aware about those activities. The target of the CSR activity is more targeted on young people who want to learn about indigo coloring techniques. Kanagoods often hold these activities for batik small industries as well.

Based on the explanation above, it is obvious that the MPR's strategy carried out by Kanagoods is a push because Kanagoods does not carry out promotions in event activities and does not use community empowerment events.

The overall analysis of this research can be stated that, there are seven strategies used by Kanagoods on Marketing Public Relation as below:

a. Improve customer awareness regarding the product.

b. $\quad$ Build the trust of brand image, the offered product and its advantages.

c. Strong commitment to improve the customer services on complaint handling for customer satisfaction.

d. Promote the new and latest update of product and make a proper plan regarding the position of old product.

e. $\quad$ Continue to communicate by $P R$ (House PR Journal) about the activities or related program, social activities in order to maintain positive publicity.

f. Maintain the company brand image, both from quantity and quality toward the customers.

\section{CONCLUSION}

The implementation related to the seven MPR's activities. The results of the analysis show that the strategy used is push with the aim of stimulating sales and facilitating communication with customers. And those strategies are quite effective to build their brand image.

After analyzing seven Marketing Public Relation strategies, it was found that the weakest strategy was Community Involvement, because Kanagoods should not only maintain relationships with stakelhoders but also ongoing relationship with public to inform the product. In publicity aspect, the media selection of Kanagoods is not optimal yet because they often used traditional media publication and only depend on bigger media industries. Therefore based on the information there are messages that do not achieve yet the right public consumer. Besides, the website of Kanagoods is not effective to update and improve their product. Kanagoods social media are only active when there is an exhibition. Kanagoods social media should update the activities of the company to make it more familiar to public.

Based on the seven MPR's strategies above, the researcher found that the most suitable activity to use was Events. However, the overall conclusion is that every strategy used by 
Handayani, J. S., Lestari, P. D. and Agave, A. (2020), "Implementation of Kanagoods marketing public relations program in creation of brand image of Batik Indigo Company", Management and entrepreneurship: trends of development, Volume 3, Issue 13, pp. 87-96, available at: https://doi.org/10.26661/2522-1566/2020-3/13-07

Kanagoods to build their brand image is considered quite effective, related to the public target, and obtaining the expected result. This can be proved in the interviews by the informants' statements in which they agree that the products produced by Kanagoods have strong branding, good quality and a unique design from similar products. Therefore Kanagoods has a good image according to its consumers.

\section{SUGGESTION}

This research can be based on using qualitative or quantitative method, or their combination. In addition, there is hope that the next researchers can use more relevant theories or concepts such as the concept of Green Market or Green Businessю Therefore the results of the research may be developed and become more useful for future research.

This research was done with the expectation to contribute to environment and related parties. By conducting more discipline of Marketing Public Relation Program, Kanagoods can reduce the advertisement cost in electronic media or offline media and the goal to build the brand image as batik indigo producer will still be achieved.

\section{REFERENCES}

Ardianto, E. (2009), Public Relations Praktis, Bandung: Widya Padjajaran, (in Indonesian).

Cangara, H. (2002), Pengantar Ilmu Komunikasi (Cetakan Keempat), Jakarta: PT Rajagrafindo Persada, (in Indonesian).

Gani, I. and Amalia, S. (2014), Alat Analisis Data: Aplikasi Statistik untuk Penelitian Bidang Ekonomi dan Sosial (edisi revi), (in Indonesian).

Harris, T. L. (2006), The Marketers's Guide to Public Relations in the 21st Century, USA: Texere Publishing.

Kementerian Perindustrian Republik Indonesia (2018), Sektor-Sektor Manufaktur Andalan Tahun 2018, Kementerian Perindustrian Republik Indonesia, (in Indonesian).

Kotler, P. and Keller, K. L. (2012), "Marketing Management”, in Pearson Education International, New Jersey: Pearson Education.

Levina, G. (2018). "5 Sustainable Indonesian Fashion Brands That You Can Wear And Save The Earth With", available at: https://www.indonesiatatler.com/fashion-beauty/fashion/5sustainable-indonesian-fashion-brands-that-you-can-wear-and-save-the-earth-with (Accessed: 1 August 2020).

Mulyanto (2016), Panduan Pendirian Usaha Kriya Batik, Jakarta: Bekraf \& Universitas Sebelas Maret, (in Indonesian).

Muzzazinah, Chikmawati, T., Rifai, M. A. and Ariyanti, N. S. (2014), Indigofera: "Kini Dan Nanti”, Proceeding Biology Education Conference, 11(1), pp. 23-26, available at: https://jurnal.uns.ac.id/prosbi/article/view/7740, (in Indonesian).

Ruslan, Rosady, SH, M. (2014), "Manajemen Public Relations \& Media Komunikasi", in Manajemen Public Relations \& Media Komunikasi, (in Indonesian).

Saputri, M. E. and Pranata, T. R. (2014), "PENGARUH BRAND IMAGE TERHADAP KESETIAAN PENGGUNA SMARTPHONE IPHONE”, Jurnal Sosioteknologi, 13(3), pp. 179-180. DOI: https://doi.org/10.5614/sostek.itbj.2014.13.3.3 (in Indonesian).

Sugiyono (2016), Metode Penelitian dan Pengembangan (Research and Development/R\&D), Bandung: Alfabeta. DOI: https://doi.org/10.1016/j.drudis.2010.11.005

Wahid, U. M. and Rizki, M. F. (2018), "Upaya Komunikasi Pemasaran Terpadu Televisi Lokal Melalui Budaya Lokal”, Jurnal Kajian Komunikasi. DOI: https://doi.org/10.24198/jkk.v6i2.15821 (in Indonesian).

Wulandari, A. (2011), Batik nusantara: maksa filosofis, cara pembuatan dan industri batik, Jogjakarta: Andi offset. 


\section{РЕАЛІЗАЦІЯ МАРКЕТИНГОВОЇ ПРОГРАМИ ПО ЗВ'ЯЗКАХ 3 ГРОМАДСЬКІСТЮ KANAGOODS В СТВОРЕННI ІМІДЖУ БРЕНДУ КОМПАНІЇ ВАТIК INDIGO}

\author{
Jihan Syavira Handayani \\ London School of Public Relations \\ Джакарта, Індонезія
}

\author{
Permata Dwi Lestari \\ London School of Public Relations \\ Джакарта, Індонезія
}

\author{
Angela Agave \\ London School of Public Relations \\ Джакарта, Індонезія
}

Kanagoods - першопроходець в виробництві батику в техніці забарвлення 3 використанням індиго в якості основного натурального інгредієнта. Компанія була створена в 2012 році і реалізує програму через впровадження маркетингових зв'язків з громадськістю, щоб створити імідж бренду як виробника батика і дослідити будь-які перешкоди, а також зусилля Kanagoods по їх усуненню. Це дослідження фокусується на 7 основних напрямках маркетингу зі зв'язків з громадськістю, включаючи публікації, події, новини, участь спільноти, інформацію або зображення, лобіювання, переговори і соціальну відповідальність. Теорія, використана в результаті цього дослідження, показала, що Kanagoods використовує концепцію маркетингових зв'язків з громадськістю Томаса Л. Xappica, а саме PENCILS, яка пояснює, чому Kanagoods використовував 7 інструментів для поліпшення іміджу. Грунтуючись на результаті, можна зробити висновок, що найбільш дієвим інструментом для використання були Events. Однак загальний висновок полягає в тому, що кожна стратегія, яка використовується Kanagoods для створення іміджу свого бренду, вважається досить ефективною, пов'язаною з публічною метою і отриманням очікуваного результату.

Ключові слова: Kanagoods, маркетингові зв'язку з громадськістю, імідж бренду

\section{РЕАЛИЗАЦИЯ МАРКЕТИНГОВОЙ ПРОГРАММЫ ПО СВЯЗЯМ С ОБЩЕСТВЕННОСТЬЮ КАNAGOODS В СОЗДАНИИ ИМИДЖА БРЕНДА КОМПАНИИ ВАТІК INDIGO}

\author{
Jihan Syavira Handayani \\ London School of Public Relations \\ Джакарта, Индонезия
}

\author{
Permata Dwi Lestari \\ London School of Public Relations \\ Джакарта, Индонезия
}

\author{
Angela Agave \\ London School of Public Relations \\ Джакарта, Индонезия
}

Kanagoods - первопроходец в производстве батика в технике окраски с использованием индиго в качестве основного натурального ингредиента. Компания была создана в 2012 году и реализует программу через внедрение маркетинговых связей с общественностью, чтобы создать имидж бренда как производителя батика и исследовать любые препятствия, а также усилия Kanagoods по их устранению. Это исследование фокусируется на 7 основных направлениях маркетинга по связям с общественностью, включая публикации, события, новости, участие сообщества, информацию или изображения, лоббирование, переговоры и социальную ответственность. Теория, использованная в результате этого исследования, показала, что Kanagoods использует концепцию маркетинговых связей с общественностью Томаса Л. Харриса, а именно PENCILS, которая объясняет, почему Kanagoods использовал 7 инструментов для улучшения имиджа. Основываясь на результате, можно сделать вывод, что наиболее подходящим инструментом для использования были Events. Однако общий вывод заключается в том, что каждая стратегия, используемая Kanagoods для создания имиджа своего бренда, считается достаточно эффективной, связанной с публичной целью и получения ожидаемого результата.

Ключевые слова: Kanagoods, маркетинговые связи с общественностью, имидж бренда. 